\title{
Multilingualism and Creativity
}




\section{BILINGUAL EDUCATION AND BILINGUALISM}

Series Editor: Nancy H. Hornberger, University of Pennsylvania, USA and Colin Baker, Bangor University, Wales, UK

Bilingual Education and Bilingualism is an international, multidisciplinary series publishing research on the philosophy, politics, policy, provision and practice of language planning, global English, indigenous and minority language education, multilingualism, multiculturalism, biliteracy, bilingualism and bilingual education. The series aims to mirror current debates and discussions.

Full details of all the books in this series and of all our other publications can be found on http://www.multilingual-matters.com, or by writing to Multilingual Matters, St Nicholas House, 31-34 High Street, Bristol BS1 2AW, UK. 


\section{Multilingualism and Creativity}

Anatoliy V. Kharkhurin

MULTILINGUAL MATTERS

Bristol • Buffalo - Toronto 


\section{Library of Congress Cataloging in Publication Data}

A catalog record for this book is available from the Library of Congress.

Kharkhurin, Anatoliy V.

Multilingualism and Creativity/Anatoliy V. Kharkhurin.

Bilingual Education and Bilingualism: 88

Includes bibliographical references and index.

1. Multilingualism-Psychological aspects. 2. Creativity (Linguistics) 3. Psycholinguistics.

I. Title.

P115.4.K43 2012

404'.2019-dc23 2012022006

British Library Cataloguing in Publication Data

A catalogue entry for this book is available from the British Library.

ISBN-13: 978-1-84769-795-0 (hbk)

ISBN-13: 978-1-84769-794-3 (pbk)

\section{Multilingual Matters}

UK: St Nicholas House, 31-34 High Street, Bristol BS1 2AW, UK.

USA: UTP, 2250 Military Road, Tonawanda, NY 14150, USA.

Canada: UTP, 5201 Dufferin Street, North York, Ontario M3H 5T8, Canada.

Copyright (c) 2012 Anatoliy V. Kharkhurin.

All rights reserved. No part of this work may be reproduced in any form or by any means without permission in writing from the publisher.

The policy of Multilingual Matters/Channel View Publications is to use papers that are natural, renewable and recyclable products, made from wood grown in sustainable forests. In the manufacturing process of our books, and to further support our policy, preference is given to printers that have FSC and PEFC Chain of Custody certification. The FSC and/or PEFC logos will appear on those books where full certification has been granted to the printer concerned.

Typeset by DiTech.

Printed and bound in Great Britain by the MPG Books Group. 
To my son Ariel 
